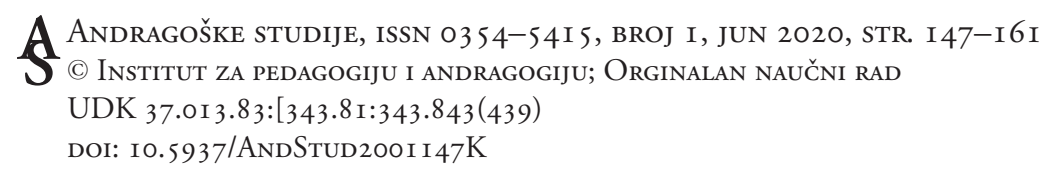

Attila Károly Molnár ${ }^{1}$, Mária Kraiciné Szokoly² Eötvös Loránd University Budapest, Hungary

\title{
Prison Andragogy or Learning Opportunities in Hungarian Prisons
}

\begin{abstract}
Successful reintegration is the goal of prison education in Hungarian penitentiaries. Prisons support prisoners with primary school education, high school education, and vocational training. These forms of learning within prison are implemented to prepare prisoners for their release, so they can integrate into the labor market afterwards (Penal Act CCXL, 2013). In the context of successful reintegration, we assume that prisoners are capable of being trained. Based on this supposition, three studies were conducted on learning and education in prison at Eötvös Loránd University Doctoral School. First, theoretical research was conducted about prison: the learning possibilities of prison, examining what it provides, what it allows, what it prevents. Second, a survey was conducted on some prisoners' perceptions of their learning opportunities. Third, an interview was carried out that has examined the perceptions of prison learning with some educators teaching in the penitentiary. Our studies on prison learning have confirmed some of our hypotheses reflected in the following statements. In Hungary, the training of prisoners is an essential part of prison life, furthermore, education can be implemented through pieces of training that can be essential tools for personal development in prison. Although most prisoners look for learning opportunities, the way they approach learning is seemingly different. Teachers who work in prison say there is a huge possibility in educating prisoners, but they would require more tools and a more functional learning environment in order to do their best.
\end{abstract}

Keywords: education in the penitentiary, learning environment in prisons, preparedness of prison-educators

\footnotetext{
${ }^{1}$ Attila Károly Molnár, M.A., PhD student, Doctoral School of Education, Faculty of Education and Psychology, Eötvös Loránd University Budapest, Hungary (molnar.attila.karoly@ppk.elte.hu).

${ }^{2}$ Mária Kraiciné Szokoly, PhD, Senior lecturer, Institute of Research for Adult Education and Knowledge Management, Faculty of Education and Psychology, Eötvös Loránd University Budapest, Hungary (szokoly. maria@ppk.elte.hu).
} 


\section{Prison Andragogy, or Learning Opportunities in Hungarian Prisons}

In the world of education and training, the new millennium has brought about a paradigmatic shift in the definition of lifelong learning by proclaiming that it includes all forms of learning, namely formal, non-formal and informal learning. In this way, lifelong learning turns into an engine of socio-economic development (European Commission, 1996; Commission of The European Communities, 2000). One statement of The European Union is that one's skills and abilities must be used as the most efficient way to gain a foothold in the labor market-regardless of how these skills were acquired. This requires an open and flexible approach that encourages lifelong learning, enabling continuous skills development (OECD, 1996). There is a need to support learning in the adult age group as well. However, in the case of adults, we need to take into account some of the adult characteristics that children do not have. Adult learning depends on an individual's life situation, social circumstances, abilities, previously acquired knowledge and skills, learning habits, learning motivation and attitude (Simándi, 2015). This statement is especially true for prisoners living in prison as they need to be supported in gaining the right competencies to participate in the world of work and law-abiding life after their release.

Our research was conducted in an interdisciplinary environment since andragogy is a sub-field of educational sciences. Increasingly we experience that new scientific results enhance the possibility of problem-solving in the field of adult learning. For example, according to some recent neurophysiological research, we may highlight neuroandragogy. One of the latest biological-neurophysiological research has exhaustively demonstrated the potential of lifelong learning: the plasticity of the nervous system ensures that we can learn throughout life. This does not mean that the learning characteristics and opportunities of a young child and an adult are identical, but it certainly ensures the possibility of lifelong learning (Carbone, 2019; Panagiotis, Georgia, \& Eleni, 2019). This encourages today's researchers to trust the training of adult prisoners.

The Hungarian Prison Service grants all prisoners an opportunity to study and provides them with material and personal conditions. However, prison statistics show that almost one in two released individuals will reoffend and then return to prison. Reducing this proportion is a matter of priority. We can expect that a more effective prison education and high-quality vocational training could both effectively improve the chances of those who complete their prison sentences to refrain from committing a crime. Therefore, we hope that the results of our research will contribute to the development of reintegration. 


\section{Study of Prison: How Prison Supports Prisoners in Learning}

\section{About International Prison Learning}

The impact of crime is problematic in many dimensions of the society, individual, labor market and family. Crime is harming a significant part of the world. Namely, prison population has tripled in the US over the past three decades, and today, about 2.3 million people are serving prison sentences (Gorgol \& Sponsler, 2011). International comparisons may also be based on data from drug-related crime investigations in European countries, according to which $37.89 \%$ of all convicted persons in Italy are sentenced for such offenses (Somogyvári et al., 2015). $18.8 \%$ of the total prison population in Austria, $13.47 \%$ in Germany and $2.88 \%$ of all convicts in Hungary were sentenced for such offenses. If we look at further domestic data, Hungarian prisons are estimated to be overcrowded by about 130\% (Várkonyi, 2018).

When we were looking for the possibility of comparing prison education in Hungary with the same reintegration opportunities in another country, we chose Slovakia. One of the reasons for our choice was that both Hungary and Slovakia belong to the former socialist region. Another reason was that Hungary has an ongoing discussion with Slovakia on prisoner reintegration. The exchange of experience between the two countries' penitentiary organizations is characterized by the fact that both countries regularly delegate professional groups to the other country. The groups spend several days with their colleagues abroad throughout their professional careers, thus expanding the possibility of cooperation (Deák, 2016).

\section{About Hungarian Prison Learning}

Effective social reintegration can only be facilitated if prisoners maintain their mental and physical condition throughout imprisonment by improving their general and vocational skills, by actively contributing to life, by studying, and by maintaining positive family and social bonding. This criminal pedagogical approach emphasizes the need for prisoners to cooperate and to be responsibly involved throughout the implementation of criminal sanctions (Ruzsonyi, 2018).

The purpose of prison enforcement in Hungary is to "promote the social integration of prisoners and the development of their law-abiding behavior" (Penal Act CCXL, 2013). There are 29 penitentiary institutions in Hungary. The purpose of after-care is to help the released prisoners reintegrate into society. 
Activities to facilitate the reintegration of prisoners include employment of prisoners, occupational therapy employment, and primary and secondary education. Prison enforcement provides higher education, vocational training, apprenticeships, and other reintegration programs (Penal Act CCXL, 2013).

In Hungary, the training of prisoners is an essential part of prison life. Education can even take place through training and can be an essential tool for personal development in prison. In defining educational methods, consideration should be given to the fact that most prisoners had already been excluded from education. It is an essential expectation that educators treat prisoners as human beings and learners and have more patience and perseverance as they are less able to master the curriculum due to a lack of education. Rather than applying stricter rules, educators need more than usual empathy and sensitivity when dealing with prisoners (Budai, 2017).

\section{A Survey: Prisoners' Perceptions of Learning Opportunities in Prison}

During the investigation, paper-based questionnaires were completed at Balassagyarmat Strict and Medium Regime Prison, in Vác Strict and Medium Regime Prison and in Györ-Moson-Sopron County Remand Prison. We wanted to find out whether the legal, material and personal conditions and opportunities meet the prisoners' learning needs and whether prisoners accept the help of the prison staff. The questionnaire consisted of five multiple-choice and four open-ended questions. The study was preceded by a trial survey, during which seven persons filled in the questionnaire. Based on quality feedback, minor changes were made to the questionnaire. The questionnaire sample was designed for 150 inmates. In total, 137 completed (among them 129 valid) questionnaires were received from prisoners at the three institutions. Participation in the survey was entirely voluntary. Participant anonymity was guaranteed, excluding the possibility of directly identifying the persons completing the questionnaires. Only aggregated data is provided in this study. Most of the respondents were aged 30-39, the youngest respondent was 20 and the oldest was 62 years old. Most of those who completed the questionnaire have primary or secondary education.

During our research, we sought answers to the following main questions: 1) What learning processes do prisoners participate in? 2) What are the prisoners' learning motives? 3) Which prison learning resources do prisoners prefer?

In all three institutions, volunteers were asked to fill in questionnaires. All elements of the prisoner population were given the same chance of being included 
in the sample. The sample in Balassagyarmat Strict and Medium Regime Prison comprised $\mathrm{N}=47$ prisoners; the prisoners completed the questionnaires on 29 April 2018. The sample in Vác Strict and Medium Regime Prison comprised N $=48$ prisoners; the prisoners completed the questionnaires on 22 May 2018. The sample in the Györ-Moson-Sopron County Remand Prison comprised N = 42 prisoners; the prisoners completed the questionnaires on 25 May 2018.

\section{Results of the Survey}

In Balassagyarmat Strict and Medium Regime Prison, out of a sample of 47, 17 respondents $(36 \%)$ indicated that they attended primary education in prison. 14 $(30 \%)$ attended some organized courses, 19 (40\%) received vocational training, $12(26 \%)$ took part in secondary school education, three inmates $(6 \%)$ received art education. Two respondents (4\%) did not participate in any learning process. Prisoners who were involved in some kind of learning process had different learning motivations. These included leaving their cell (2.4\%), earning money $(4.9 \%)$, curiosity $(4.9 \%)$, schooling $(4.9 \%)$, pastime $(4.9 \%)$, resocialization (12.2\%), professionalization (24.4\%), and self-development (41.5\%). According to the questionnaire, in Balassagyarmat, individual learning paths are more important for prisoners than organized learning processes. The respondents most often mentioned some informal learning forms: individual reading, television, and radio.

In Vác Strict and Medium Regime Prison, out of a sample of 48, 29 respondents $(60 \%)$ indicated that they attended primary education in prison. Two of them (4\%) attended some organized courses, seven (15\%) received vocational training, two (4\%) took part in secondary school education, one inmate $(2 \%)$ received art education. Four respondents $(8 \%)$ did not participate in any learning process. Prisoners who were involved in some kind of learning process had different learning motivations. These included earning money (5.6\%), pastime (5.6\%), professionalization (11.1\%), schooling (19.4\%), resocialization $(16.7 \%)$, and self-development (41.7\%). Prisoners are affected to varying degrees by different learning processes. According to the questionnaire, regarding the sources of knowledge acquisition at the Vác institution, individual learning paths are more important among prisoners than organized learning processes. The respondents most often mentioned some informal learning forms: individual reading, television, radio. Some prisoners indicated that they were gaining new knowledge in other ways, too, from the Bible, talking with correspondents, personal conversations, and crossword puzzles. 
In Györ-Moson-Sopron County Remand Prison, out of a sample of 42, one respondent $(2 \%)$ indicated that he attended primary education in prison. One (2\%) attended some organized courses, five (12\%) received vocational training, two $(5 \%)$ took part in secondary school education, six inmates $(14 \%)$ received art education. 15 respondents (36\%) did not participate in any learning process. Prisoners who were involved in some kind of learning process had different learning motivations. These included resocialization (4.8\%), self-development (9.5\%), schooling (23.8\%), pastime (23.8\%), and leaving their cell $(38.1 \%)$. Prisoners are affected to varying degrees by different learning processes. According to the questionnaire, in the Györ institution, individual learning pathways are more important for prisoners than organized learning processes. The respondents most often mentioned some informal learning forms: individual reading, television, and radio. Some prisoners indicated that they could gain new knowledge by other means, such as solving crossword puzzles.

\section{Interview Study with Educators Who Teach in Prisons}

We conducted an interview study with sixteen educators working in some Hungarian prisons. We paid particular attention to the strengths and weaknesses of the inmates and searched for their learning motivation. We asked what factors were conducive to learning and what conditions in prison hindered the learning of prisoners. Looking at the teachers' learning support work, we were curious about the ways to make learning in prison easier and what ideas they could use to make their teaching work more effective.

The purpose of the interview study was to learn about the forms of education, training, and learning provided to prisoners in their prison, the learning environment available within prison, the learning conditions and the need for teachers to make the teaching-learning process feasible and successful. Furthermore, we studied how they complement the learning conditions provided by the institution. Interview questions focused, among other things, on existing and missing tools for learning support, and whether the penitentiary organization is working to improve teachers' professional methodologies to make reintegration learning effective and efficient.

In our research method we used accessibility sampling. A common trait of the 16 interviewees is that they are not employees of the prison organization and that all of them work in non-prison education institutions. In addition to their activities, they carry out pedagogical work in prison institutions at the request of prison organizations. The average age of the respondents was 53 , six of them 
were women and ten of them were men. Nine had university degrees, five had college degrees, one was an educator, and one was a baccalaureate. Among the respondents, there were three technical trainers. In terms of teaching qualifications, the group consisted of a history teacher, a mathematics teacher, a biologychemistry teacher, a chemistry-physics teacher, a biology-geography teacher, a math-physics-chemistry teacher, a psycho-teacher mentor, a Hungarian-Russian teacher, and an English-andragogy teacher. In addition to the above persons, we interviewed a commercial marketing economist and a tailor. The interviewees were motivated by curiosity, the educational and reintegration potential of prisoners, the invitation from different institutions, the opportunity to earn money, and the challenge of prison pedagogical work. Respondents typically believe in the importance of prison education.

The research was carried out between July 1, 2019, and August 31, 2019 in non-prison locations in Dunaújváros, Veszprém, Balassagyarmat, Balatonfüzfö, and Budapest. We did not conduct content analysis when analyzing interview responses, as this method is not relevant for a small number of interviews. Instead, we present quotes from the text of interview responses to support our findings. We had four main hypotheses and our third hypothesis included three sub-hypotheses.

\section{Results of the Interview}

According to our first hypothesis, prisoners in prisons can be trained similarly to other disadvantaged groups, but their training should take greater account of the learning characteristics of their social, economic and socio-cultural disadvantage. During training in prisons, trainers seek to take into account the social, economic and socio-cultural disadvantages of prisoners. They include regular praise, encouragement, differentiated classroom work, and teamwork. Educators, knowing the background of the prisoners' family, strive to structure their classes in such a way that students from a variety of socio-cultural backgrounds receive the information they need. To this end, prison educators need to know to some extent the students' family background, which occurs only through informal conversations between educators and prisoners. However, such conversations are forbidden by prison rules - in the dialogue between teachers and students, educators should strive for purely professional communication. Nonetheless, prison educators have access, through the prisoners' narratives, to information that is expected to result in more effective teaching than some change in the teaching method. Prison teachers typically consider it important, in addition to passing on material 
knowledge, that the learning prisoners also acquire key competences for lifelong learning.

"It is a success if the inmates' attitude changes when they understand why they are here and if they feel any empathy for the victim." (Interviewee no. 4, male, aged 53, teacher of physics and chemistry)

To encourage learners, when one is uncertain, the teacher personally addresses them to avoid losing their learning motivation.

"Come to the blackboard and I'll help you! I go there and help them with their work. So I try to maintain their attention so that they do not think about their family or what has happened to them." (Interviewee no. 2, male, aged 58, teacher of mathematics)

Prison classes provide an opportunity for differentiated teaching organization. If the educator detects a student lagging in the curriculum, he or she will try to help them catch up. Educators use a variety of motivational strategies. These include rewards, involvement in teamwork and even into education, and building on the knowledge gained.

"I try to get them involved so they can share their own experiences. I have to build on my own experience because they have virtually no power of conception." (Interviewee no. 5, female, aged 68, teacher of biology and geography)

"Additional motivation: asking students with professional knowledge of the subject (e.g. finance and accounting graduates) to cooperate with the teacher during the lesson." (Interviewee no. 10, female, aged 50, teacher of trade marketing)

According to our second hypothesis, there is a limited range of adult learning tools available to prisoners in a prison setting. It is essential to provide a learning environment and use teaching and visual aids in the teaching of prisoners. In their absence, teacher preparation for the lesson and maintaining students' attention is questionable. In the penitentiary institutions where the teachers we interviewed work, it was a fact that the learning environment was unfavorable and the physical means were lacking. This problem affects both the quality of students' and teachers' participation in the learning process: gaps in quantity, quality and accessibility have a direct impact on prison pedagogical work.

"Chemistry and physics should involve experimentation. There is scarce equipment for performing experiments." (Interviewee no. 4, male, aged 53, teacher of physics and chemistry) 
"We couldn't go into the warehouse when we wanted to. We couldn't go out to work because no supervisor in the corridor would let us out." (Interviewee no. 9, male, aged 73, teacher of science)

"No textbooks, no colored chalk, we were not allowed to bring in visual aids." (Interviewee no. 5, female, aged 68, teacher of biology and geography)

To reduce the lack of teaching aids, it is sometimes the teachers themselves (sometimes the learners!) who made a financial sacrifice for their education by purchasing the missing teaching aids themselves.

"I was provided with a very simple, old-fashioned classroom with one board and three chalks. I contribute in the only way I can-I bring in photocopies, I print papers, graduation assignments, and pictures." (Interviewee no. 3, male, aged 33, teacher of biology and chemistry) "I needed a dictionary from a shelf_-it was missing." (Interviewee no. 13, male, aged 65, teacher of Hungarian grammar and literature and Russian language)

Due to the prison's by-laws, lock-in, rigid nature of institutional hierarchy and supervisory security, it seems inevitable that some of the security provisions will have a negative impact both on prisoners' learning and the teaching staff. This is mainly manifested in the fact that some teaching aids are difficult or not accessible at all, so they are not available in class.

"Material conditions are tight. For convenience, I relied heavily on the "blackboard and chalk teaching" and my own voice. You must have special permission to bring in a flash drive." (Interviewee no. 4, male, aged 53, teacher of chemistry and physics)

"We had to get permission for everything, even the ironing water. If we didn't get confirmation by the next day, we didn't iron the next day." (Interviewee no. 14, female, aged 54, teacher of tailoring)

The quantity, quality, location, availability of the material supporting learning is a determining factor in the quality of the learning-teaching process. According to the interviewees, the poor quality of devices hinders the learning process.

"Quite old sewing machines were picked up from storage. The sewing machine maintenance man came in ... he only made the machine worse." (Interviewee no. 10, male, aged 54, teacher of commercial marketing) 
The design and implementation of classrooms and the learning environment supporting adult education, as well as the design and implementation of safety equipment and their use, should support the prison learning-teaching process. If these conditions are not well-planned, we must consider them a barrier to learning.

"The whole prison environment is in such poor condition, it is very depressing. A small windowless room like this! And so they provided it to us." (Interviewee no. 4, male, aged 53, teacher of physics and chemistry) "We were in a very small room, 19 of us were locked in, sweating, 2 had to learn to work on one machine. The profession that takes three years to master had to be taught in a year and a half. When we ran out of material, many times I brought in materials from my workshop. The obstacle is that they can't bring anything from their cell." (Interviewee no. 14, female, aged 54, teacher of tailoring)

Personnel conditions for adult education include the movement of student inmates within the institution between cells and classrooms. This will require a sufficient number of staff members, otherwise, the relevant persons will not be escorted to the classrooms or the library.

"They don't get to visit the library either. Many times they complain that they want to go to the library to read or borrow a dictionary, but they can't get there. This is because there are very few supervisors, no one to accompany them." (Interviewee no. 1, female, aged 31, teacher of history and English)

The use of computers and the internet in prisons is generally prohibited for prisoners.

"What I missed was the use of internet during lessons. Or at least one interactive whiteboard!" (Interviewee no. 15, male, aged 62, teacher of technical subjects)

"We need more IT tools. The internet is forbidden in prison! There are separate benches, empty walls, a green board... All of this makes it basically impossible to teach a 60-year-old computer literacy!" (Interviewee no. 3, male, aged 33, teacher of biology and chemistry)

"We are in a very difficult situation. We have no textbooks, no map, no nothing. I teach from the atlases I got from school before. When one of my classes graduated, I said, kids, give me the atlases, because you won't need them anyway in high school! I collected them and took them 
to the jail. And we only have five atlases in a class of thirty students!"

(Interviewee no. 5, female, aged 68, teacher of biology and geography)

According to our third hypothesis, (a) to meet the specific learning needs of prisoners, there is a need to improve the preparedness of teachers in prisons; (b) there is no organized teacher in-service training for incoming teachers; (c) teachers adapt to the needs of the target groups through self-training. Prisoners require special attention and methodological consideration because of their status and environmental characteristics (i.e. because of the crime they committed, they are serving their sentence in a closed institution). Teachers involved in prison pedagogical work were not, or were only marginally prepared for this special task at the outset of their work in institutions. Teachers develop the skills necessary to meet the challenges of prison teaching in practice, without the assistance of a prison organization in this process of development; there is no training to improve prison educators. External teachers catch up to the demands of prison teaching by self-development in this way. Prison teachers use specific methods to work in prisons differently compared to outside school practice. Priority will be given, inter alia, to personal role models, credibility, catching up with students, and differentiated classroom work.

"I can rely on credibility over and over again, this is my method." (Interviewee no. 12, female, aged 49, vocational teacher of light industry) "Some students completed their tasks fairly quickly, whereas others needed my help. They were competing with each other, wow! I was basically all over the place throughout the class." (Interviewee no. 14, female, age of 54, teacher of tailoring)

"I worked with small groups who had a hard time doing the task. I gave more serious tasks to those who found the basic task very simple." (Interviewee no. 15, male, aged 62, teacher of technical subjects)

According to our fourth hypothesis, predicting andragogy-based prison education can be used to successfully develop prisoners' key competences for lifelong learning, with dedicated learning methodology and tools. To determine the success rate of prison pedagogical work, it would be necessary to follow those who have obtained a certificate and have already been released, as the training is aimed at supporting integration into the labor market. Thus, the results are difficult to determine during the time prisoners study in prison. The interviewed teachers themselves make it possible to determine the learning successes after the release, but no information is available on the possible successes of the participants from this period. The number of people who obtain some kind of final certification as a result of prison education is extremely low. 
"It is a small success when someone completes their grade. It is a huge success if they can obtain their high school diploma. I know that in three prisons about one or two out of 5000 complete it." (Interviewee no. 2, male, aged 58, teacher of mathematics)

Not only, and not specifically, acquiring material knowledge may be considered a success.

"The social and cultural development of prisoners is just as important as decisive. It is not teaching but rather education that is very important in bringing our students to life and reintegrating them into society. Reintegration is very important." (Interviewee no. 3, male, aged 33, teacher of biology and chemistry)

"Social value judgment and empathy towards others is important. I also consider it a success if someone continues their schooling after release, if they still need to study. Success is when they complete a year. These are concrete, measurable successes." (Interviewee no. 4, male, aged 53, teacher of chemistry and physics)

"One of the pillars of success is a supportive educator attitude." (Interviewee no. 13, male, aged 65, teacher of Hungarian grammar and literature and Russian language)

\section{Summary}

The education of prisoners in prisons is a matter of social interest since education is a prerequisite for prisoners' release into society. The higher one's education, the more likely he or she is to find a job in the labor market. A significant number of adults who leave prison again commit a crime and, as a result, return to prison, leaving them unable to participate in the world of work and falling out of the rhythm of social life. We believe that the reduction of relapses may depend on the level of education of the prisoners being released, so we have examined the legal, material and personal conditions for the education of prisoners in order to find opportunities for improvement in prison education.

Studies show that efforts are being made by both the prison system and teachers who teach inmates to achieve effective prison education. At the same time, it has become evident that today's form of education still leaves much to be desired. Material and personal factors affect the quality of prison education. In many cases, tools that are indispensable to education, such as classroom equipment, writing materials or learning aids, are missing. Educators make great efforts 
to maintain the quality of lessons but are unable to overcome their limitations. Prison does not educate trainers, they have to attain knowledge themselves, and they have to develop their own strategies for better education. Prison staff also have a lot of work to do, which is why they may not be able to support detainees in class, so students regularly miss classes.

\section{Conclusions and Recommendations}

As prison education is an important factor in preparing prisoners for life, it is clear that everything must be done to improve education. We see the implementation of development in three areas. On the one hand, it would be worthwhile to arrange classroom conditions so that both students and teachers find a smooth and goal-oriented lesson. Prison educators say that more attention should be paid to creating conditions for the education of prisoners. This includes enabling them to prepare for classes, providing teaching aids and training teachers. It is their vision that a comprehensive development could improve the efficiency of prison training for prisoners and their preparation for life. On the other hand, it would be necessary to increase the number of prison staff members to move prisoners between the cells and classrooms on time. Finally, it is essential to facilitate contact between teachers teaching in prisons (even by use of a common web-based document that could be shared among teachers) to consult regularly and jointly identify their needs to support the development of their teaching quality.

\section{References}

BudaI, G. (2017). Fogvatartottak képzése és foglalkoztatása a Pálhalmai Országos Büntetés-végrehajtási Intézetben (Training and employment of prisoners at the Pálhalma National Penitentiary). Börtönügyi Szemle, 36(1), 5-19. https://bv.gov. hu/sites/default/files/B\%C3\%B6rt\%C3\%B6n\%C3\%BCgyi\%20Szemle\%20 2017\%201.pdf

Carbone, A. (2019). "Neuroandragogy against exclusion" project as a response to EU policy on adult education, with particular emphasis on the education of adults from disadvantaged groups. In K. Czekaj-Kotynia (Ed.), Neuroandragogy against exclusion - Strategy, Recommendations and Good Practices (pp. 11-18). Łódź: Społeczna Akademia Nauk w Łodzi.

Commission of the European Communities (2000). A Memorandum on Lifelong Learning, Brussels: Commission of the European Communities. 
DeÁk, F. I. (2016). Eseménynaptár(Calendarofevents). BörtönügyiSzemle, 35(1), 130-136. https://bv.gov.hu/sites/default/files/B\%C3\%B6rt\%C3\%B6n\%C3\%BCgyi\%20 Szemle\%202016\%201.pdf

European Commission (1996). White Paper on Education and Training. Teaching and Learning. Towards the Learning Society. Retrieved from http://europa.eu/documents/comm/white_papers/pdf/com95_590_en.pdf

Gorgol, L. A., \& Sponsler, B. A. (2011). Unlocking Potential: Results of a National Survey of Postsecondary Education in State Prisons. Issue brief. Retrieved from http://www.ihep.org/sites/default/files/uploads/docs/pubs/unlocking_potentialpsce_final_report_may_2011.pdf

OECD (1996). Lifelong Learning for All - Policy Directions. Retrieved from http://www. oecd.org/officialdocuments/publicdisplaydocumentpdf/?cote=DEELSA/ED/ CERI/CD(2000)12/PART1/REV2\&docLanguage=En

Panagiotis, A., Georgia, G., \& Eleni, L. (2019). Neuroandragogy in class instead of Andragogy. Pilot course for adult immigrants in Kalamata Second Chance School within the framework of fighting social exclusion. In K. Czekaj-Kotynia (Ed.), Neuroandragogy against exclusion - Strategy, Recommendations and Good Practices (pp. 27-34). Łódź: Społeczna Akademia Nauk w Łodzi.

Penal Act CCXL (2013). Retrieved from https://net.jogtar.hu/jogszabaly?docid= A1300240.TV

Ruzsonyi, P. (2018). Rendszerben látni, rendszerben gondolkodni: stratégia és didaktika (To see in a system, to think in a system: strategy and didactics). Börtönügyi Szemle, 37(4), 77-87. https://bv.gov.hu/sites/default/files/ B\%C3\%B6rt\%C3\%B6n\%C3\%BCgyi\%20Szemle\%202018\%204.pdf

SimÁNDI, Sz. (2015). Kutatások a felsöoktatásban és a felnöttképzésben (Research in higher education and adult education). Retrieved from http://p2014-25.palyazat.ektf. hu/public/uploads/1-kutatasok-a-felsooktatasban-es-a-felnottkepzesben-simandiszilvia-isbn_565d54f96e457.pdf

Somogyvári, M., Drexler, B., Banyárné, S. L., \& Rutkai, K. (2015). Kábítószerbűncselekményt elkövető fogvatartottak (Prisoners committing drug offenses). In M. Somogyvári (Ed.), 2015/1 Börtönstatisztikai Szemle (Prison Statistics Review) (pp. 16-34). Budapest: Büntetés-végrehajtás Országos Parancsnoksága. Retrieved from https://bv.gov.hu/sites/default/files/B\%C3\%B6rt\%C3\%B6nstatisztikai\%20Sze$\mathrm{mle} \% 202015 \% 202 . p d f$

VÁRKonyI, Zs. (Ed.). (2018). 2018/1 Börtönstatisztikai Szemle (Prison Statistics Review). Retrieved from https://bv.gov.hu/sites/default/files/BvOP/Kiadvanyok/Bortonstatisztikai\%20Szemle\%202018\%201.pdf 


\section{Andragogija u zatvoru ili prilike za učenje u mađarskim zatvorima}

Apstrakt: Uspešna reintegracija jeste cilj obrazovanja u zatvoru u mađarskim zatvorskim ustanovama. Zatvori pružaju podršku zatvorenicima kada je reč o osnovnom, srednjem i stručnom obrazovanju. Ovi vidovi učenja u zatvoru primenjuju se kako bi se zatvorenici pripremili za izlazak iz zatvora i kako bi nakon toga mogli da se uključe na tržište rada (Krivični zakonik Mađarske, CCXL, 2013). U kontekstu uspešne reintegracije, pretpostavljamo da su zatvorenici sposobni da pohađaju određenu obuku. Pošli smo od te pretpostavke i sproveli tri studije o obrazovanju i učenju u zatvoru pri Doktorskoj školi Univerziteta Eötvös Loránd. Kao prvo, sproveli smo teorijsko istraživanje o prilikama za učenje u zatvoru i onoga što zatvor pruža, omogućava i sprečava. Kao drugo, sproveli smo anketu o percepciji pojedinih zatvorenika o njihovim prilikama za učenje. Konačno, sproveli smo intervjue sa određenim nastavnicima koji drže nastavu u zatvorima o tome kako oni vide učenje u zatvoru. Ova studija o učenju u zatvoru potvrdila je neke od naših hipoteza koje smo formulisali sledećim tvrdnjama. U Mađarskoj je obuka zatvorenika neophodan deo boravka u zatvoru. Osim toga, obrazovanje može da se primeni u vidu obuke koja može da pruži osnovne alatke za lični razvoj u zatvoru. Iako većina zatvorenika traži prilike za učenje, način na koji pristupaju učenju je naizgled drugačiji. Nastavnici koji rade u zatvoru tvrde da postoji velika mogućnost obrazovanja zatvorenika, ali da su im potrebna dodatna pomagala i funkcionalnije okruženje za učenje kako bi uložili maksimalan napor u nastavi.

Ključne reči: obrazovanje u zatvoru, okruženje za učenje u zatvorima, pripremljenost nastavnika za nastavu u zatvorima

\footnotetext{
${ }^{3}$ Attila Károly Molnár, MA, student doktorskih studija, Doktorska škola obrazovanja pri Fakultetu obrazovanja i psihologije, Univerzitet Eötvös Loránd, Budimpešta, Mađarska (molnar.attila.karoly@ppk.elte.hu).

${ }^{4}$ Dr Mária Kraiciné Szokoly, viši predavač na Institutu za istraživanje obrazovanja odraslih i upravljanje znanjem pri Fakultetu obrazovanja i psihologije, Univerzitet Eötvös Loránd, Budimpešta, Mađarska (szokoly. maria@ppk.elte.hu).
} 